\title{
Forced Evictions and Black-Indigenous Land Rights in the Marvelous City ${ }^{12}$
}

\author{
Jennifer Chisholm
}

\section{Introduction}

The 2014 World Cup and impending Olympic Games in 2016 have exacerbated and publicized the grave issue of forced evictions in Brazilian cities. Following a 2014 report from the Comitê Popular da Copa e das Olimpíadas, development projects relating to the mega-events have caused the evictions of approximately 3,500 families. Moreover, construction for the 2016 Olympics threatens about 5,000 families in Rio de Janeiro (Garcia and Ramos 2015, 97). The majority of those affected in Rio de Janeiro are AfroBrazilians from the lower classes living in favela (informal housing) settlements. While favelas have existed and collectively have been an integral part of the city since its inception, favela residents, or favelados, typically do not possess land titles because favelas are informal settlements unsanctioned by Rio's municipal government, leaving favelados ill equipped to fight against evictions and dispossession by the Military Police (dos Santos 1996, 73; Fischer 2008, 219; OHCHR 2014, 21; Garcia and Ramos 2015, 79).

Though violence and forced evictions are common experiences for the most marginalized of Brazilian society, some groups have more legal recourse than othersnamely those that can prove that their land is necessary for the continuance of their unique cultures. In Brazil, the groups who can prove that their ways of life are

\footnotetext{
${ }^{1}$ The author, unless otherwise noted, has translated all quotations.

${ }^{2}$ Portions of this article appear in Chisholm (2015)
} 
significantly different from the dominant Brazilian culture and so enjoy additional rights to land are indigenous Brazilians and quilombolas. "Quilombolas" describes descendants of escaped African and Afro-Brazilian slaves who formed rural maroon colonies (quilombos in Portuguese) during Brazil's colonial era.

In Rio de Janeiro, an urban quilombo community called Quilombo Sacopã and Aldeia Maracanã, a community of indigenous squatters, have been relatively successful in their fight to actualize land rights (including the right to occupy or own land) when compared to the usual defeats favelados endure. For both communities, acknowledgement of land rights by the municipal government has fallen short of actual land title, or land ownership; in fact, Brazilian public policy dictates that indigenous tribes have no entitlement to land that the State already claims. However, the federal government does recognize the right of quilombos and indigenous groups to inhabit their lands (Seed 2001, 137). The right to live on but not own land alternatively refers to "native title" in Australia, New Zealand, and the United States and to "aboriginal title" in Canada (Seed 2001, 132-3). Despite these protections, both communities have faced multiple eviction attempts and one successful eviction in the case of Aldeia Maracanã, which nevertheless maintains some authority over the building from which the Military Police evicted them. In this article, I explore why and how Quilombo Sacopã and Aldeia Maracanã have been more efficacious in their quest for land and property rights compared to favela inhabitants. I also examine why, despite these rights, they are still under the same threats of forced eviction and police violence as people living in favelas.

I contend that Aldeia Maracanã and Quilombo Sacopã have had success with land rights while so many favelados continue to struggle because they have been able to leverage existing laws that recognize the right for quilombos to occupy and own land and grant native title to indigenous Brazilians. Although quilombo land rights and native title normally apply to rural land, Aldeia Maracanã and Quilombo Sacopã have 
argued that the same rights apply to urban land. Furthermore, they have constructed a narrative of cultural preservation (as opposed to rhetoric that emphasizes racial justice and reparations) that has led to greater support for their causes. I make a secondary argument that these extra laws have not been effective because of discrimination and inefficient and apathetic governments (local and federal) that have not prioritized actualizing land rights for minority groups.

For the methodology, I analyzed texts comprised of primary and secondary sources. The analysis heavily relies on journalistic publications, blog posts from Aldeia Maracanã and Quilombo Sacopã members, and key Brazilian legislation and relevant United Nations statutes and other publications. I included these statutes because, as I will later explain, the United Nations has had significant influence over policymaking in Brazil. Focusing on journalistic articles ensured the most up to date information given that the struggles of both communities are effectively current events. Notwithstanding, there are several scholarly sources on Quilombo Sacopã and Aldeia Maracanã (Dodebei and Werneck 2014; Mendonça 2010; Mendonça 2011; Pereira 2014; Rodríguez 2013).

The inspiration and theoretical framework for this article is Juliet Hooker's (2005) "Indigenous Inclusion/Black Exclusion: Race, Ethnicity and Multicultural Citizenship in Latin America." In the article, Hooker argues that indigenous people in Latin America have more collective rights (which include land and property rights) than Afrodescended people because governments do not think Afro-Latinos have a distinct culture from the national culture. The only exception to this rule are palenques, quilombos, and other maroon colonies of ex-slave descendants, which are geographically and socially isolated enough from dominant societies that Latin American governments accept their claims to having unique cultures worth preserving. Therefore, governments consider these maroon colonies to be similar to indigenous 
communities due to a common narrative of struggle and land as being necessary for cultural preservation (Hooker 2005, 295).

Hooker examines several identity-based social movements in Latin America and concludes that when groups position their demands in terms of preserving culture, they are more successful than movements that emphasize legal reparations for historical racism, since many Latin Americans deny the existence of racism in their countries $(2005,297,308)$. Hooker's findings are especially salient in the cases of Aldeia Maracanã and Quilombo Sacopã, who primarily frame their struggle for land rights in terms of maintaining their ways of life, as opposed to anti-racism rhetoric. This tactic has provided both communities with several legal protections. However, discrimination, coupled with ineffective and lackadaisical governance, explain why Aldeia Maracanã and Quilombo Sacopã remain threatened despite laws that recognize their land rights. The conclusion of this article emphasizes the importance of finding solutions to land rights violations and briefly discusses one possible short-term solution for favelas.

Given that housing is a universal right and that land is necessary for the maintenance of human life, it is important to identify instances in which dispossession attempts fail owing to the compliance of at least some aspects of land and property rights laws. It is equally important to acknowledge the unfulfilled promises and shortcomings of laws that intend to protect land and property rights. Finally, the ultimate futility of native/aboriginal title laws and abstract ideas about housing rights that are sometimes codified into law proves the continued necessity for indigenous people, quilombolas, favelados, and others with land and housing needs to strive towards property title and land ownership. Moreover, the failure of these laws requires marginalized people and their allies to demand improved governance and obliges them to pursue the amelioration of discriminatory structures that impede the realization of these rights. 


\section{United in a Common Struggle: Aldeia Maracanã and Quilombo Sacopã}

Aldeia Maracanã is a multiethnic community of indigenous people living in Rio de Janeiro. Indigenous people traveling to Rio to speak with politicians about the needs of their villages found themselves in need of housing, so they began to occupy an abandoned mansion next to the Maracanã soccer stadium in the early 2000s (Fernandez 2013; Notícias Rio Brasil Editor 2013). On October 20, 2006, the Aldeia became a permanent settlement of more than seventy people from seventeen different tribes, including the Pataxó, Tukano, Guajajara, and Apurinã, who moved there to be closer to health and educational resources of the city (CEDEFES 2013). It also functioned as a community center where people could discuss issues relevant to indigenous people inside and outside of the city (Fernandez 2013).

The settlement became permanent after a vote by thirty-five members of the Movimento Tamoio dos Povos Originários (Tamoio Movement of Original Peoples), a name that evokes the Confederação dos Tamoios (Confederation of Tamoios), which was an alliance among Tupí tribes against Brazil's Portuguese colonizers. This movement predates the Aldeia Maracanã community who chose the building for its historic relation to native issues and for being the site of historic exchanges between Tupí tribes and the Portuguese settlers. In this sense, they saw occupying the building as a way to reclaim the land of their ancestors (Dodebei and Werneck 2014, 48; CEDEFES 2013).

Before the occupation of the building (eventually assuming the name "Aldeia Maracanã") by the indigenous squatters, it was the private residence of Duque Saxe, who commissioned its construction in 1862. In 1889, the new republican Brazilian Government acquired the building and converted it into the Brazilian Ministry of 
Agriculture, Industry, and Trade. Later, in 1910 it became the first institute in Brazil dedicated to research about indigenous people and then the headquarters of FUNAI, the National Indian Foundation (Fernandez 2013; Jornal do Brasil, “Movimento" 2013). When FUNAI (the federal bureau in charge of indigenous affairs) moved to Brazil's capital, Brasília, the Government repurposed the antique mansion again into the first Museu do Índio in 1953, founded by acclaimed Brazilian anthropologist and indigenous advocate, Darcy Ribeiro. Once the Government moved the Museu do Índio to a more centrally located building in Rio's Botafogo neighborhood in 1977, it remained empty until members of the Aldeia Maracanã settled there thirty years later (Romero and Barnes 2013).

After years of autonomy, Aldeia Maracanã and the eponymous community faced eviction due to construction projects for the 2014 World Cup and 2016 Olympic Games in Rio. Sérgio Cabral (the state governor of Rio de Janeiro at the time), pushed for the expulsion of the community in order to expand the Maracanã stadium complex and envisioned demolishing the old Museu do Índio as well as a neighboring school, aquatic sports center, and stadium among other buildings (CEDEFES 2013; Romero and Barnes 2013). In their place, he proposed the creation of a massive parking lot for 2,000 cars, a mall, and a soccer museum. Estimates placed the cost of the project at R\$ 800 million, or $£ 260$ million (Fernandez 2013).

Pushbacks against this plan were severe and the Aldeia's imminent expulsion drew the attention of domestic and international supporters. These allies included Brazilian celebrities Chico Buarque, Milton Nascimento, and Caetano Veloso, as well as Raquel Rolnik (the UN Special Rapporteur on adequate housing during the time of the 2014 World Cup) and scores of academics, students, and other human rights activists (Sánchez 2013; Jornal do Brasil, “Aldeia” 2013). Moreover, Amnesty International started the Enough Forced Evictions campaign in response to the generally high rate of 
forced evictions in Rio-more than 19,000 families between 2009 and 2013 (Bowater 2014; Amnesty International 2013).

Despite popular support, 200 police officers forcibly entered Aldeia Maracanã on March 22, 2013 using tear gas and pepper spray to force the twenty remaining indigenous people and one hundred of their supporters to leave (Romero and Barnes 2013). Further re-occupations and evictions took place in October and December of that year by State Military Police of Rio de Janeiro (Garcia et al. 2015, 427). In the spirit of compromise, some members of the community agreed to stay in a former leper colony on the periphery of Rio in Jacarepaguá and recently, they moved again to centrally located social housing apartments funded through the federal housing program, Minha Casa, Minha Vida (Notícias Rio 2013; de Andrade 2014). Currently, the community is working with state and municipal governments to redesign and repurpose the former museum into an indigenous cultural center and learning space (Associação Indígena 2015).

Explaining the violence against Aldeia Maracanã, Dauá Puri, one of the leaders of the village, declared during a meeting in the Aldeia building on January 18, 2013:

“O que estão querendo fazer é um processo de invisibilidade da cultura indígena. Isso é um espaço sagrado e que precisa ser respeitado." (ASFUNRIO 2013)

What they are trying to do is to start a process of making indigenous culture invisible. This [Aldeia Maracanã] is a sacred space that needs to be respected.

For another leader, cacique Carlos Tukano, police violence does not deter him from trying to return to the Aldeia, which he sees as the rightful property of his people: 
Sempre carregamos nossas Tabas $^{3}$ em nossas mentes e corações, pois sempre fomos nômades neste grande território que vocês chamam de Brasil, que consideramos nosso. Cada chão que pisamos é nossa casa...Desde então vivemos correndo das cercas, e agora do spray de pimenta. Estamos acostumados. Por isso é com satisfação que aceitamos o convite dos nossos parentes da família Sacopã, para refundarmos lá simbolicamente a Aldeia Tamoio, que já foi tudo que vocês chamam hoje de Rio de Janeiro. (Romão 2012)

[We always carry our Tabas in our minds and hearts, because we have always been nomads in this large territory that you call Brazil, which we consider ours. All the land on which we walk is our home...Since then, (Portuguese colonization) we have lived running from fences, and now from pepper spray. We are used to it. So we are pleased to accept the invitation of our relatives from the Sacopã family, to symbolically reestablish Tamoio Village, which was all that you call today Rio de Janeiro.]

Carlos Tukano was speaking at the Quilombo Sacopã, who hosted members of the Aldeia for feijoada and who in turn participated in a taba ceremony of the Aldeia. The Aldeia Maracanã likely found solace in the company of Quilombo Sacopã because of their shared difficulties in securing land rights for their communities.

\footnotetext{
3 "Taba" is the Tupi-Guarani word for "aldeia", or village (Dicionário).
} 
Quilombo Sacopã is the only federally recognized urban quilombo in Rio de Janeiro (Braga 2011). It is located in the wealthy zona sul (South Zone) area of the city, in the neighborhood of Lagoa (Menezes 2012; Braga 2011). The story of the quilombo commences in the late 1920s when Mara Rosa da Conceição do Carmo, her husband Manoel Pinto Jr., and their five children left a coffee plantation in Nova Friburgo and moved to Rio de Janeiro (Menezes 2012). At the time, the area was a thick forest and was mostly uninhabited, but rapid urbanization and favelização (an increase in favela communities) changed the landscape drastically. The area became wealthy in the 1960s and 1970s when the government implemented a draconian policy of destroying favela communities and banishing low-income families to the peripheries of the city (Perlman 2010, 296; Menezes 2012). In the South Zone alone, more than 150,000 people living in favelas lost their homes from 1968-1975 (Mendonça 2011, 4). During this time, Quilombo Sacopã lost land to make room for two buildings and the City Government tried to evict the community, citing that they were occupying the land illegally (Menezes 2012; Manenti 2014). Resisting eviction, the quilombo became a rural enclave within an urban, wealthy area and the first urban quilombo in the state of Rio de Janeiro (Menezes 2012).

A demographic study completed in 2006 by INCRA (Instituto Nactional de Colonização e Reforma Agrária) placed the number of people living in Quilombo Sacopã at six families with forty-two people living on 3.2 hectares of land (LACED 2014). Other sources place the size of the community at twenty-six people from six families on 2.4 hectares of land (Braga 2011; Menezes 2012). Mendonça (2011) attests that Quilombo Sacopã resides on $6404.17\left(.64 \mathrm{~m}^{2}\right)$ of land $(2011,2)$ while Rodríguez (2013) claims that initially, INCRA allocated 22,900 $\mathrm{m}^{2}$ (2.29 hectares) to the Quilombo but after complaints from neighbors, reassessed the total land area to $6,900 \mathrm{~m}^{2}$, or .69 hectares $(2013,94)$. The discrepancy in these figures is curious and perhaps troubling if accurate demographic information of the community is unavailable. Notwithstanding, a common 
theme of land and population loss emerges from the data. It is unclear why the Quilombo has lost people and land, if these figures are correct, but the community has been facing pressure from developers (purportedly backed by the City Government) to surrender their lands. One real estate developer, Pronil, tried to acquire land belonging to the Quilombo, stating that their intention was to donate the land as a nature reserve (Menezes 2012). Turning the area into a nature reserve-what Rodríguez (2013) calls the "monumentalização da natureza [creating monuments out of natural spaces]" $(2013,96)$ would have effectively evicted the Quilombo community.

Another recent threat occurred in August 2012 when police blocked off the Quilombo from street access to prevent revelers attending the community's famous samba and feijoada parties that had taken place there since the 1970s. The action came after the Resident's Association of Fonte da Saudade voted to ban these gatherings because of their raucousness (Braga 2011; Menezes 2012; Romão 2012). Quilombo Sacopã will likely face more impingements on their rights but ideally have safeguards from eviction. In 2005, the Fundação Cultural Palmares granted the community the title "comunidade quilombola [quilombo community]". The Fundação, operating within the Ministry of Culture, is in charge of identifying quilombos and initiating the process of getting land titles for these communities. Despite the support of the Federal Government, Quilombo Sacopa still does not have ownership to the land on which they live but they are protected in a sense by law from being evicted (Maneti 2014).

\section{Why Forced Evictions Are Indefensible: Security of Tenure, Squatters' Rights, and the Right to the City}

Municipal and federal laws that grant protections for indigenous people and quilombolas are the result of years of mobilization on the part of indigenous and non- 
indigenous activists to secure rights for themselves and other vulnerable populations. These laws have empowered communities like Aldeia Maracanã and Quilombo Sacopã to demand land rights in Rio de Janeiro, stating that although indigenous and quilombo land rights laws normally concern rural communities, these laws are still applicable in urban contexts. Furthermore, advocates of Aldeia Maracanã's fight to reclaim the building use a broad understanding of land rights, such that "land" can also refer to the property situated on the land.

The United Nations also interprets the concept of land broadly and states, "The use of the term 'lands'...shall include the concept of territories, which covers the total environment of the areas which the people concerned occupy or otherwise use" (ILO qtd. in Assies 2000, 93). Legal support for the demands of Aldeia Maracanã, Quilombo Sacopã, and favela residents exists in several UN statutes, including the right of Security of Tenure, as well as the City Statute of Brazil.

Indigenous Brazilian and quilombo land rights activism must been seen in a larger context of indigenous social movements throughout Latin America, which generally have been successful in raising awareness about indigenous sovereignty and land justice. Efforts of transnational indigenous movements have globalized indigenous rights, garnering support from international organizations like the United Nations, as well as from various NGOs and funding bodies (Yashar 2005, 16). Generally, indigenous rights activists are mainly concerned with anti-discrimination, environmental issues, and land tenure (Carvalho 2000,461). Land tenure as a basic human right is one of the fundamental principles of the United Nations Commission on Human Rights, which assesses the status of human rights (especially for minority and other socially marginalized populations) around the world. The United Nations defines an aspect of land rights, "security of tenure" as:

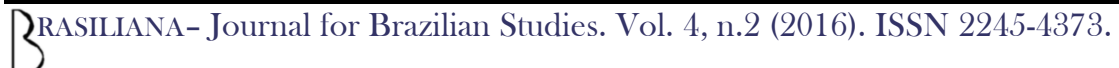


....a set of relationships with respect to housing and land, established through statutory or customary law or informal or hybrid arrangements, that enables one to live in one's home in security, peace and dignity. It is an integral part of the right to adequate housing and a necessary ingredient for the enjoyment of many other civil, cultural, economic, political and social rights. All persons should possess a degree of security of tenure that guarantees legal protection against forced eviction, harassment and other threats. (Rolnik 2013, 3-4)

As a facet of the right to adequate housing, secure tenure should be stable, affordable, safe, and environmentally sound accommodation that is reasonably near to necessary resources such as schools and hospitals (OHCHR 2014, 4). Security of tenure and the right to adequate housing encompass more than simply the right to a dwelling; they also recognize the right for everyone to "a home and community, to enjoy physical and mental health, and to live in safety, peace, and dignity (SAHRC 2011, 26)." Moreover, the right to adequate housing implies certain freedoms, including "freedom of movement" (OHCHR 2014, 3). The Brazilian State violates the rights to adequate housing and security of tenure when it forcibly evicts favela communities, restricted Quilombo Sacopã from street access, and dispossessed the Aldeia Maracanã community, forcing them to relocate to Rio's periphery.

Besides security of tenure, the United Nations' defense of squatters' rights strengthens property claims of Aldeia Maracanã. Their arguments for why they have the right to live in the former Museu do Índio follow from UN definitions of adequate housing, which include the right to occupy abandoned spaces, considering the shortage of housing in urban and rural areas: 
The legal recognition of the rights of those occupying public, private or community land and housing for a prescribed period, through adverse possession of land and housing, above the rights of absentee owners or the State, is an important measure to ensure that land and housing is being used in the most socially productive manner and to fulfill the right to adequate housing for all. (Rolnik 2013, 8)

Therefore, the United Nation allows for those with housing needs, like Aldeia Maracanã, to ignore the property rights of those who own abandoned buildings when there is an opportunity to increase access to housing through "adverse possession" or squatting. In addition to the United Nations, the Brazilian Constitution also protects squatters' rights. For example, Article 183 of the Brazilian Constitution recognizes usucapião of urban land used for a home after five years of occupation without interruption or opposition, provided the occupier does not own any other property (Rolnik 2013, 8).

The "right to the city", a concept developed by French Marxist sociologist Henri Lefebvre, also supports the claims of both the Aldeia Maracanã and Quilombo Sacopã as well as all favela dwellers. In the Right to the City, Lefebvre insists that every member of an urban society, especially the marginalized, has a "right to urban life" and so should have access to all of the resources of the city (Lefebvre 1996, 158). Inspired by this ideal, Brazilian activists pushed for the inclusion of this principal in the 1988 Constitution (Perlman 2010, 311). However, it would take an additional thirteen years for this "movement for the right to the city" to produce legislative change: the 2001 City Statute of Brazil, Federal Act No. 10.527/01 (Perlman 2010, 311; Maricato 2010, 22). The City Statute requires that municipal governments provide "guidelines for infrastructure development in areas occupied by low-income populations; regularization of land titles; 
neighbourhood impact studies; and the creation of "special zones of social interest'" (Isensee 2013; Kothari 2004, 8). Temporarily withholding judgment on the ultimate effectiveness of Brazilian laws reflecting the right to the city, squatters' rights and security of tenure, these laws at least theoretically support land and property claims of low-income, housing insecure Brazilians. Additional protections exist for indigenous Brazilians and quilombolas that may explain the modest land rights successes of Quilombo Sacopã and Aldeia Maracanã.

The Advantages of Images and Perceptions of Indigeneity on Brazilian Land Rights Laws

The rhetoric of Aldeia Maracanã and Quilombo Sacopã perhaps best explains their land rights successes. In keeping with the theories presented in Hooker (2005), both communities have emphasized in their arguments the necessity of land for cultural preservation as the basis of land rights as opposed to demanding land as reparations for previous discrimination. In doing so, they were able to call on federal laws and international statutes that recognize indigenous need for land for cultural reasons and convince Rio's municipal government to pass laws that echo similar sentiments. Additionally, indigenous and quilombola activists, following Gayatri Chakravorty Spivak's (1990) theory of strategic essentialism, capitalized on indigenous stereotypes in a "performance of authenticity" in order to achieve their land rights goals (Sullivan 2013, 467). In the following section, I demonstrate how laws (which are in addition to squatter's rights, security of tenure, and rights to the city) that protect them evince the influence of cultural preservation rhetoric. I then explain an essentialist take on indigenous and quilombola people as the earth's natural caretakers forms the basis of cultural preservation narratives. Though undoubtedly originating in the real importance 
of land to indigenous cultures around the world, essentialist discourse, while politically effective, runs the risk of promoting counterproductive stereotypes.

Cultural preservation narratives espoused by Quilombo Sacopã and Aldeia Maracanã find their source in views of Brazilian indigenous people and quilombolas as having unique, timeless unadulterated cultures, being close to nature, and on their importance to the national heritage of Brazil and Brazilian national identity. Perceptions of all native peoples as so-called stewards of the earth facilitate land rights claims because of a conventional belief that indigenous people naturally live in harmony with the land and will take care of it better than would more urbanized, non-indigenous people (Merchant 2002, 140; Tsosie 1996, 312).

In fact, the UN also assumes an intimate relationship between the environment and native peoples:

Indigenous peoples and their communities and other local communities have a vital role in environmental management and development because of their knowledge and traditional practices. States should recognize and duly support their identity, culture and interests and enable their effective participation in the achievement of sustainable development. (Rio Declaration qtd. in Xanthaki 2007, 261)

The United Nations has played an important role in the history of indigenous rights in Brazil and yet indigenous land rights in Brazil predate UN involvement. For example, the Indian Statute of 1973 demarcated the Brazilian Amazon for indigenous use as part of the military government's "nationalist project of rooting Brazilian heritage in its indigenous history" (French 2009, 25-6). Nevertheless, Brazil did not consider nation- 
wide indigenous land rights until Brazil became a democratic republic after the creation of its constitution in 1988.

Following the end of military rule and the creation of a constitutional democracy in Brazil, the Brazilian Government adopted a supremacy clause in their constitution that assents to make any UN statute that it ratifies a part of national law. Consequently, when the United Nations' International Labour Organization (ILO) implemented Convention 169, "Concerning Indigenous and Tribal Peoples in Independent Countries", Brazil ratified it and agreed to view its indigenous people as having special, inherent rights to land and culture (Assies 2000, 93; Maybury-Lewis 2003, 328). These rights come not from the nation-state but come from their status as original occupants of the land and therefore precede the modern nation-state (Bolanõs 2011, 56-7). The foundation of current laws for indigenous and quilombo land rights in Brazil is ILO Convention 169.

ILO Convention 169 as national law has paved the way for more detailed laws regarding indigenous and quilombo land rights. For instance, the National Policy for Sustainable Development, inaugurated on February 7, 2007, gives rights to "traditional people" as long as they are living sustainably or harmoniously with nature. The policy defines traditional people "as those groups who recognize themselves as culturally distinct, maintain their own forms of social organizations, and occupy and use territories and natural resources for their cultural, social, religious, and economic reproduction" (Bolanõs 2011, 53). This legislation mostly pertains to native Brazilians but according to this definition, quilombo communities are traditional communities as well (Bolanõs 2011, 54).

In Brazilian federal law, Quilombos are legally analogous to indigenous communities because of their unique cultural history and relationship to land (Pinheiro 
2013) and article 68 of the Brazilian Constitution explicitly guarantees land regularization for quilombos:

Aos remanescentes das comunidades dos quilombos que estejam ocupando suas terras é reconhecida a propriedade definitiva, devendo o Estado emitir-lhes os títulos respectivos. (Brazilian Constitution)

[The State] recognizes the outright ownership of lands that are occupied by descendants of quilombo communities and will send them their respective land titles.

Unlike indigenous Brazilians, the State permits and even encourages land ownership for quilombos. The reasons for the special allowance are beyond the scope of this essay but certainly warrant inquiry. Additionally, article 216 of the Constitution defines the cultural rights of quilombo communities that, according to the Government, have social significance in the history of Brazil because of their role in resisting slavery and thus are symbolic of a larger nationalist resistance against the Portuguese Empire:

Constituem patrimônio cultural brasileiro os bens de natureza material e imaterial, tomados individualmente ou em conjunto, portadores de referência à identidade, à ação, à memória dos diferentes grupos formadores da sociedade brasileira, nos quais se incluem...os conjuntos urbanos e sítios de valor histórico, paisagístico, artístico, arqueológico, paleontológico, ecológico e científico... Ficam tombados todos os documentos e os sítios detentores de reminiscências históricas dos antigos quilombos. (Brazilian Constitution) 
[The Brazilian cultural heritage assets of material and immaterial nature, taken individually or together, bear reference to identity, action and memory of the various groups of Brazilian society, which include ... urban complexes and sites of historical, natural, artistic, archaeological, paleontological, ecological and scientific value ... All documents and historical sites belonging to the descendants of quilombos are protected.]

However, despite the promises of the State, of the more than 3,500 quilombos in Brazil, most have not received land titles, which could secure their land rights and prevent forced evictions (Pinheiro 2013).

Given the proximity of quilombo identity to Brazilian indigenenity, Brazil values the conservation of quilombo land and culture as a way to honor Brazilian heritage. For example, on August 16, 2011 the city council of Rio de Janeiro declared Quilombo Sacopã to be an "Área Especial de Interesse Cultural", or a "Special Area of Cultural Interest" because of the special place it holds in the history and culture of Rio de Janeiro (City Council 2011). A "Special Area of Cultural Interest" is a kind of "[Area] of Interest" and so is a product of the City Statute federal law. The City Government of Rio de Janeiro defines "Special Area of Cultural Interest" as:

Aquel[es]... Sítios Culturais, definidos no art. 140 desta Lei Complementar, por conservar referências ao modo de vida e cultura carioca, necessária à reprodução e perpetuação dessas manifestações culturais. (City Council 2011, art. 70). 
Those...Cultural Sites, as defined in article 140 of the Lei Complementar, that preserve the carioca culture and way of life [and] that [are] necessary for the reproduction and perpetuation of these cultural forms.

Reminiscent of the way indigenous Brazilians embody Brazil's past in the popular imagination, the City Government of Rio distinguishes Quilombo Sacopã as one of the architects of Rio's “culture and way of life". The law establishing Quilombo Sacopã as a "Special Area of Cultural Interest" means that in theory, this law should protect the Quilombo from urbanization measures that have been threatening the community.

In addition to codified laws that protect land rights for native Brazilians and quilombolas, there are governmental agencies that overlook the application of these rights. INCRA, the National Institute of Colonization and Agrarian Reform within the Ministry of Agrarian Development, provides support for quilombo communities. Specifically, the agency oversees the process of identifying potential quilombos and helping them begin the process of land regularization and securing titles for their land (INCRA 2014). In addition, the Fundação Cultural Palmares endeavors, as previously mentioned, to preserve Afro-Brazilian culture and defend quilombo communities (Menezes 2012). For those seeking redress for violations against indigenous rights, the Ministério Público Federal as well as the General Board for the Defense of the Rights and Interests of Indigenous Populations handle such cases (Kothari 2004, 16). However, as I will show in the next section, these statutes and oversight institutions are not enough to guarantee rights.

Politically, Quilombo Sacopã and Aldeia Maracanã have been successful in positioning themselves as preservationists of Brazil's cultural history in order to take advantage of special land rights for quilombolas and indigenous Brazilians. Aldeia 
Maracanã has, for the most part, portrayed itself as traditionalists (living in but not of the city) and as conservationists. During the period when the indigenous squatter community faced eviction, pressure from the Aldeia's allies compelled the City Government to pass "Law Project no. 1536" on September 20, 2012, which upheld Aldeia Maracanã's right to occupy the building and the land surrounding it, citing "cultural, historical, and architectural" importance (City Council 2011). One of the reasons that members of the Aldeia were able to garner legal support for their claim to the derelict Museu do Índio building was through their assertion that they were preserving the building by occupying it. Additionally, by choosing to live in that particular building, they not only conserved it but imbued it with cultural, historical, and aesthetic significance as well.

The widely accepted perception of indigenous people as innate conservationists belies a more complex history. In the colonial era when debates about the humanity of indigenous people were taking place, similar debates ensued over whether indigenous people were natural conservationists or just as antagonistic to the natural landscape as anyone else (Bolanõs 2011, 53). Proponents of indigenous people as antagonistic thought that any human interference in nature led to its destruction. This view is still relevant today since, for example, some nature conservationists have argued against Quilombo Sacopã's right to land because they believe that the Quilombo threatens the local forest (Braga 2011).

Luís Sacopã, the head of the Quilombo, argues that his family will continue to look after the land in a sustainable way in the tradition of his ancestors:

[Luís] afirma que uma das principais características do quilombo é a preservação ambiental, herdada de uma consciência ecológica de seus antepassados." (qtd. in Menezes 2012) 
[Luís] affirms that one of the characteristic principles of the quilombo is environmental preservation, inherited from an ecological consciousness from his ancestors).

By suggesting that ecological consciousness is a long-standing custom of his community, Sacopã attempts to align himself with traditional views of indigenous people-an understandable tactic considering the strong perceived connection between indigenous people and their land. I do not make this observation to criticize the environmentalism of Quilombo Sacopã, but only to emphasize that the survival of Quilombo Sacopã depends on their continued perception as having an intimate connection with and being caretakers of their land in a way that is indicative of indigeneity.

People who have little to no connection to indigeneity but who also have housing needs, like favela residents, are at a disadvantage in relation to indigenous people and quilombolas when it comes to claiming the right to use and occupy land, since they cannot prove they need land in order to sustain their cultures. In fact, popular opinion denies favela residents having a particular culture or history (Scheper-Hughes 1992, 90), although they arguably have both by nature of living in favela communities. For instance, the favela Providência (also threatened with removal) has existed longer than Quilombo Sacopã; it was founded in 1897 as Rio's first favela and is an important heritage site of Afro-Brazilian culture (Soares 2013, 2-3; Williamson and Hora 2012). Likewise, favelas Santa Marta and Babilônia are UNESCO World Heritage Sites because they lie within the boundaries of the "cultural landscape of Rio de Janeiro" (Rolnik, 2012). Despite this, the Brazilian Government assumes that those who live in favelas are not only antagonistic to their environment but that favelas expose Brazil's serious 
problems with poverty, which they worry make them appear as an underdeveloped nation (Romero and Barnes 2013). This may explain (at least partially) why the State, through forced evictions, seems determined to eradicate them (Imas and Weston 2012, 209).

An essentalist take on cultural preservation, one whose argument bases itself on common stereotypes of indigeneity, has political weight but is fraught with problems. Firstly, putting the onus of conserving history on indigenous and quilombo communities is problematic because it incorrectly assumes that they are untouched by the passing of time and that their cultures never change (Bolanõs 2011, 54). Equally, viewpoints that essentialize native people as natural conservationists deny multifaceted expressions of indigeneity that have little to do with rural land. For instance, young indigenous Brazilians from the Amazon living in cities are constantly negotiating what it means to be indigenous in an increasingly globalized world (Virtanen 2012, 177-196). Urban spaces, as well as ancestral rural lands, help to shape new senses of self and culture, which are still indigenous yet multicultural at the same time. Furthermore, the internet and social media provide virtual spaces in which indigenous people can connect with each other in order to preserve their traditions or explore other ways of knowing and being. Finally, framing discussions about indigenous and quilombola land rights in terms of cultural and ecological preservation instead of land rights as restitution for colonial wrongs may be more effective politically, but this framework concomitantly silences important yet infrequent discussions among Brazilians about the damaging colonial legacies of indigenous dispossession and slavery in Brazil. 


\section{Disadvantages and Barriers to Quilombo and Indigenous Land Rights}

When compared to favela residents and others with insecure housing who aspire to land and housing rights, native Brazilians and quilombo communities arguably have more avenues for recourse because of laws that specifically protect their rights to land and property, institutions designed to carry out these laws, and the perceived close connection between their cultural survival and access to land. However, several limitations to these recourses make, for instance, the struggles of Aldeia Maracanã and Quilombo Sacopã similar to those of favela communities in Rio de Janeiro, making both communities as susceptible to forced evictions and police violence as favela residents. Class and racial discrimination, as well as an ineffective and apathetic government, render property and land protections virtually useless for impoverished quilombolas and indigenous Brazilians.

In the absence of a welfare state, Brazil's poor not only have limited access to lifesustaining resources, but they also must contend with a federal government whose policies rarely reflect the concerns of the poor due to their disdain for the lower classes as antagonistic to economic growth (Freeman 2014, 31; Garcia et al. 2015, 415). Furthermore, because favelas are informal settlements, impoverished favela residents cannot obtain property titles, putting them at greater risk of being forcibly evicted (OHCHR 2014, 21). Poor indigenous people, similarly, have "insecure tenure" over their traditional lands and "are more likely than other groups to live in inadequate housing conditions [,] and will often experience systemic discrimination in the housing market" (OHCHR 2014, 27-8). In this sense, race and class converge to create a racialized oppression of the poor that fundamentally denies them the most basic rights to property and land. 
In a departure from cultural preservation rhetoric identified as the most successful approach in Hooker (2005), Luís Sacopã, the leader of Quilombo Sacopã, expressed his frustrations with his experiences of racism and classism when discussing the police blockades of the community in August 2012:

Eles tentam nos prejudicar de qualquer maneira. Para mim, isso é racismo. Estão tirando o nosso direito de ir e vir. São pessoas que se dizem poderosas, mas que só sabem prejudicar os outros...A vizinhança reclama dos encontros, mas a minha família está aqui há mais de 105 anos. Já sofremos todo tipo de violência por sermos pobres e morarmos numa área rica. (qtd. in Braga 2011)

[They try to discriminate against us by any means. To me, that is racism. They are taking our right to come and go. They are people who call themselves powerful, but they only know how to discriminate against others...the neighbors complain about the events, but my family has been here for more than 105 years. We have already suffered all types of violence for being poor and living in a rich area.]

Sacopã relates a common experience of police harassment by poor black, indigenous, and other non-white Brazilians - all of whom are overrepresented in accounts of police violence (French 2013,161). Although a majority of Brazil's Military Police is non-white, Military Police officers carry out the bidding of the majority-white State that, like with the poor, demonizes black Brazilians and other non-whites (French 2013, 169-171). Racial discrimination and ensuing police violence against poor racial/ethnic minorities 
inevitably prohibit the obeisance to laws designed to safeguard the rights of these marginalized groups.

Another reason that indigenous and quilombolas cannot enjoy the full extent of their land rights is because of bureaucratic dysfunction. In his 2004 report on the status of adequate housing in Brazil, former Special Rapporteur for the UN Human Rights Council Miloon Kothari noted that the Brazilian Government had passed several laws, like the City Statute, which uphold the right to housing and access to urban resources. He warned, however, that the "fragmentation" of government agencies would likely hinder the ability of the government to carry out these laws (Kothari 2004, 7-8):

The historical legacy of decades of racial discrimination and neglect of the poor is a gigantic challenge...According to the Government, the overlapping jurisdiction between federal, state and municipal actors with regard to urban and rural housing creates difficulties and has had a detrimental impact on the effectiveness of housing policies since the mid-1980s... While many of the existing projects and initiatives that the Special Rapporteur has come across are individually positive, creative and innovative, he perceives a lack of coordination and cross-linkages. As a result, positive, and even excellent initiatives become ad hoc interventions. (Kothari 2004, 7)

The problems with implementing the land rights laws of Quilombo Sacopã and Aldeia Maracanã are in keeping with the issues Kothari illuminated in the above quotation. In the passage, Kothari laments how a muddled bureaucracy has prevented efforts to redress housing inequalities born of racism and disdain for the poor. Thus, government 
fragmentation allows structural inequalities to continue to exist, despite laws that aim to combat them.

Governmental inefficiency means that laws that protect the land rights of Aldeia Maracanã and Quilombo Sacopã, without proper enforcement, are devoid of any real meaning. Perhaps cynically, these laws may also be what Brazilians colloquially term "para inglês ver" laws. Para inglês ver (literally, "for the English to see") is any superficial law or agreement whose sole function is merely to appease concerned groups (Murilo 2002, 46). The history of the term begins in England where in 1807, the government abolished the slave trade within the British Empire after a successful campaign by Quaker abolitionists. Hoping to further curb slave trading, England signed an agreement with Portugal in 1810 and a treaty in 1815, but Portugal continued participating in the slave market (Ashcroff 2015).

Undeterred, England instead turned its attention to the newly independent Brazil. In exchange for recognizing its independence, England demanded in an 1827 treaty that Brazil free its enslaved population. In response, Brazil promised to end slave trade within three years of the treaty and passed "Feijo's Law" in 1831 that equated buying and selling slaves with piracy, an already illegal activity at the time (Murilo 2002, 45; Ashcroff 2015). In reality, Feijo's Law did not end slave imports to Brazil and instead serves as the inspiration for the expression, "para inglês ver" (Murilo 2002, 45).

Current policies regarding construction projects for the World Cup and Olympics that privilege the interests of the tourism industry over those of favelados seem to operate as para inglês ver, also known by the acronym "PIV" (Ashcroff 2015). Equally, Law Project no. 1536 for Aldeia Maracanã, Quilombo Sacopã's special status as an Area of Cultural Interest, and other indigenous and quilombola land rights statutes at city, state, and federal levels could prove to be merely hollow precepts designed to ingratiate a supranational entity-in this case, the United Nations. PIV laws help give the 
semblance of a progressive postcolonial state dedicated to righting the wrongs of indigenous dispossession and exploitation but effectively pollute the justice system and create false hope.

In addition to PIV laws, governmental apathy toward the plight of the disenfranchised manifests in its neoliberal economic policies that subordinate land and property rights of indigenous Brazilians, quilombolos, and favelados alike to real estate development interests. Although envisioned as opportunities for economic stimulus in Brazil's cities, the World Cup and Olympic Games have threatened the livelihoods of Brazil's economically disadvantaged populations by dislocating those without land titles and gentrifying poor neighborhoods (Garcia and Ramos 205, 79, 80). A Brazilian neoliberal government bent on amassing surplus capital portrays the lower, or "popular" classes as antagonistic to "processos de acumulação [accumulation processes]" and so become the enemy of neoliberal economic development (Garcia et al. $2015,415)$.

In Rio de Janeiro, "neoliberal governance" by politicians sympathetic to the needs of free market capitalism allows for the abandonment of traditional rules regarding infrastructure and housing during periods of "exception", notably during mega-events (Freeman 2012, 97). As a result, local and international businesses and corporations have taken advantage of the more favorable atmosphere to increase their capital through "state-assisted privatization and commodification of the urban realm..." (Sánchez and Broudeboux 2015,3) by dispossessing or attempting to dispossess favela dwellers, Quilombo Sacopã, and Aldeia Maracanã of their lands and property (Freeman 2012, 122). It seems evident that due to discrimination and indifferent (or at best, dysfunctional) governance, laws acknowledging land rights for quilombolas and indigenous Brazilians cannot fully protect these groups from the threat of dispossession. 


\section{Conclusion and Considerations for the Future}

In this article, I have outlined the catastrophic effects that the 2014 World Cup and 2016 Olympic Games have had on Brazil's urban poor and housing insecure. A segment of this population, indigenous Brazilians and Afro-Brazilian quilombolas, notionally have more recourse against attempts to evict them from urban land and property if they are able to prove that the land they occupy is necessary for the continuation of their unique cultures. These additional resources have generated legal protections for two communities, Quilombo Sacopã and indigenous squatters Aldeia Maracanã. Both of these groups have been somewhat spared from the epidemic of forced evictions plaguing favela communities that are being undertaken during a special period in which neoliberal development projects commence while willfully ignoring the disastrous effects of these projects on the poor.

Looking forward, further research could attempt to discover possible ways to circumvent the limitations of indigenous and quilombola land rights laws or to discover the circumstances under which these laws are successfully enforced, if ever. Taking into account the present foundation for indigenous and quilombo land rights in Brazil, despite the barriers to its actualization, additional investigation could attempt to ascertain the possibility for some favelas to adopt a rhetoric of cultural or ecological preservation in the interest of short-term survival. For example, the Complexo do Alemão favela complex, which borders the last remaining part of the Altlantic Forest in the North Zone of Rio, is currently undergoing urban forest restoration initiatives in their community to preserve the last of the Atlantic Forest. To promote the endeavor, Alemão residents created the documentary, "Olhares da Misercórdia" with funding from the federal government, awarded for promoting "access to culture" (Jacobs 2015). 
Potentially, locals could try to secure the favela's future by emphasizing their role as urban conservationists. Of course, such actions require assessing the financial and social costs of such an enterprise. At any rate, the constraints that have kept Quilombo Sacopã and Aldeia Maracanã from realizing their land rights prove that structural changes need to happen in Brazilian governance and in Brazilian society before one could hope for genuine land, property, and housing rights for Brazil's racially and economically marginalized population.

\section{References}

Amnesty International. 2013. "Basta de remoções forçadas!" September 18. Accessed June 22, 2015. https://anistia.org.br/noticias/basta-de-remocoes-forcadas/.

de Andrade, Hanrrikson. 2014. "No RJ, índios temem virar, caricatura em prédio do Minha Casa, Minha Vida." UOL, June 30. Accessed July 10, 2015. http://noticias.uol.com.br/cotidiano/ultimas-noticias/2014/06/30/no-rj-indios-tememvirar-personagens-em-predio-do-minha-casa-minha-vida.htm.

ASFUNRIO AULA [Associação dos Servidores da SMDS e FUNDO RIO]. "Dauá Puri Aldeia Maracanã" (video). Posted January 18, 2013. Accessed June 23, 2015. http://www.youtube.com/watch?v=kcii-k8qds8.

Ashcroff, Patrick. 2015. "Two Centuries of Conning the 'British': The History of the Expression 'É Para Inglês Ver,' or 'It's for the English to See' and Its Modern Offshoots." RioOnWatch (blog), May 28. Accessed July 14, 2015. http://www.rioonwatch.org/?p=21847.

Assies, Willem. 2000. "Land, Territories, and Indigenous Peoples' Rights." In Current Land Policy in Latin America: Regulating Land Tenure under Neo-liberalism, edited by Annelies Zoomers and Gemma van der Haar, 93-110. Amsterdam: KIT Publishers.

Associação Indígena Aldeia Maracanã. 2015. "Projeto preliminar para o restauro do prédio do antigo Museu do Índio." April 4. Accessed June 22, 2015. 
http://aldeiamaracana.com/2015/04/04/projeto-preliminar-para-o-restauro-do-predio-doantigo-museu-do-indio/.

Bolanõs, Omaria. 2011. "Redefining Identities, Redefining Landscapes: Indigenous Identity and Land Rights Struggles in the Brazilian Amazon." Journal of Cultural Geography 28, no 1 (February): 45-72. Accessed May 5, 2014. http://dx.doi.org/10.1080/08873631.2011.548480.

Bowater, Donna. 2014. "In Brazil, World Cup Means Evictions." Washington Post, $\begin{array}{llll}\text { January } 25 . & \text { Accessed June 23, }\end{array}$ http://www.washingtonpost.com/world/the_americas/for-some-in-brazil-world-cupmeans-evictions/2014/01/24/73799036-7f83-11e3-9556-4a4bf7bcbd84_story.html.

Braga, Ronaldo. 2011. "Justiça lacra entrada de carros do Quilombo do Sacopã, na Lagoa, para impedir festas comerciais no local." O Globo, July 9. Accessed June 23, 2015. http://oglobo.globo.com/rio/justica-lacra-entrada-de-carros-do-quilombo-do-sacopa-nalagoa-para-impedir-festas-comerciais-no-local-2718454\#ixzz34YyLJzI3.

Carvalho, Georgia O. 2000. "The Politics of Indigenous Land Rights in Brazil." Bulletin of Latin American Research 19, no. 4: 461-478. Accessed April 15, 2014. http://dx.doi.org/10.1111/j.1470-9856.2000.tb00119.x.

Centro de Documentação Eloy Ferreira da Silva (CEDEFES). 2013. "Carta aberta à imprensa e a todos que apoiaram à Aldeia Maracanã e o Movimento Tamoio dos Povos Originários." March 29. Accessed June 23, 2015. http://www.cedefes.org.br/index.php?p=indigenas_detalhe\&id_afro=10040.

Chisholm, Jennifer. 2015. "Written on the Walls." King's Review, December 15. http://kingsreview.co.uk/magazine/blog/2015/12/15/written-on-the-walls/\#top.

City Council of Rio de Janeiro. 2011. Ementa: Cria área de especial interesse cultural AEIC do Quilombo Sacopã (Projeto de lei no. 1092). By city counselors Eliomar Coelho and Reimont. Accessed June 23, 2015. http://mail.camara.rj.gov.br/APL/Legislativos/scpro0711.nsf/1061f759d97a6b24832566ec0 018d832/e82f59271b28ef77832578ee006a2836?OpenDocument.

Dicionário Ilustrado Tupi Guarani. “Taubaté." Accessed July 17, 2015. http://www.dicionariotupiguarani.com.br/dicionario/taubate/. 
Dodebei, Vera, and Marcela Werneck. 2014. "Movimentos sociais e a demolição do complexo do Maracanã." Congresso Internacional Interdisciplinar em Sociais e Humanidades, Salvador, Bahia: Universidade Católica do Salvador, October 8-10. $\begin{array}{lll}\text { Accessed } & \text { December 22, }\end{array}$ http://aninter.com.br/Anais\%20CONINTER\%203/GT\%2021/03.\%20DODEBEI\%20WERN ECK.pdf.

Fernandez, Nayana. 2013. “Aldeia Maracanã Marks 513 Years of Indigenous Evictions in Brazil." Latin America Inside Out (blog). Latin American Bureau, March 19. Accessed June 23, 2015. http://lab.org.uk/aldeia-maracana-rios-urban-indigenous-village-in-danger-asbrazils-world-cup-approaches.

Fischer, Brodwyn. 2008. A Poverty of Rights: Citizenship and Inequality in Twentieth Century Rio de Janeiro. Stanford: Stanford University Press.

Freeman, James. 2014. "Raising the Flag over Rio de Janeiro's Favelas: Citizenship and Social Control in the Olympic City." Journal of Latin American Geography 13, no. 1: 7-38. Accessed July 11, 2015. http://dx.doi.org/10.1353/lag.2014.0016.

. 2012. "Neoliberal Accumulation Strategies and the Invisible Hand of Police Pacification in Rio de Janeiro." Revista de Estudos Universitários 38, no. 1: 95-126.

French, Jan Hoffman. 2013. "Rethinking Police Violence in Brazil: Unmasking the Public Secret of Race." Latin American Politics and Society 55, no. 4: 161-181. Accessed June 26, 2015. http://dx.doi.org/10.1111/j.1548-2456.2013.00212.x.

2009. Legalizing Identities: Becoming Black or Indian in Brazil's Northeast. Chapel Hill, NC: University of North Carolina Press.

Garcia, Demian Castro and Patricia Ramos Novaes. 2015. "Copa do Mundo 2014 e os impactos no direito à moradia: uma análise das cidades-sede brasileiras." In Brasil: os impactos da Copa do Mundo 2014 e das Olimpíadas 2016, edited by Orlando Alves dos Santos Junior, Christopher Gaffney, Luis Cesar de Queiroz Ribeiro. Rio de Janeiro: Observatório das Metrópoles.

http://www.observatoriodasmetropoles.net/images/abook_file/livro_megaeventos_2015. pdf. 
Garcia, Demian Castro, Christopher Gaffney, Patricia Ramos Novaes, Juciano Rodrigues, Carolina Pereira dos Santos, and Orlando Alves dos Santos Junior. 2015. "O projeto Olímpico da cidade do Rio de Janeiro: reflexções sobre os impactos dos megaeventos esportivos na perspectiva do direito à cidade." In Brasil: Os Impactos da Copa do Mundo 2014 e das Olimpíadas 2016, edited by Orlando Alves dos Santos Junior, Christopher Gaffney, Luis Cesar de Queiroz Ribeiro. Rio de Janeiro: Observatório das Metrópoles.

http://www.observatoriodasmetropoles.net/images/abook_file/livro_megaeventos_2015. pdf.

Hooker, Juliet. 2005. "Indigenous Inclusion/Black Exclusion: Race, Ethnicity and Multicultural Citizenship in Latin America." Journal of Latin American Studies 37, no. 2 (May): 285-310. Accessed June 12, 2014. http://dx.doi.org/10.1017/S0022216X05009016.

Imas, Miguel J. and Alia Weston. 2012. "From Harare to Rio de Janeiro: Kukiya-Favela Organization of the Excluded." Organization 19, no. 2 (March): 205-227. Accessed April 29, 2014. http://dx.doi.org/10.1177/1350508411429397.

INCRA. 2014. "Quilombolas." Accessed July 18, 2015. http://www.incra.gov.br/estrutura-fundiaria/quilombolas.

Isensee, Patrick. 2013. "What Is The Right to the City?" RioOnWatch, October 16. Accessed June 23, 2015. http://www.rioonwatch.org/?p=11668.

Jacobs, Sarah. 2015. “Juventude do Complexo do Alemão cria documentário para promover floresta urbana da Zona Norte." RioOnWatch, May 27. Accessed July 18, 2015. http://rioonwatch.org.br/?p=14319.

Jornal do Brasil. 2013. "Aldeia Maracanã: Caetano Veloso crítica 'vulgaridade' da administração estadual." January 20. Accessed June 23, 2015. http://www.jb.com.br/rio/noticias/2013/01/20/aldeia-maracana-caetano-veloso-criticavulgaridade-da-administracao-estadual/.

. 2013. "Movimento Meu Rio entra na luta pela preservação do Museu do Índio." January $18 . \quad$ Accessed June 2015. http://www.jb.com.br/rio/noticias/2013/01/18/movimento-meu-rio-entra-na-luta-pelapreservacao-do-museu-do-indio/. 
Kothari, Miloon. 2004. Report on adequate housing as a component of the right to an adequate standard of living, Mission to Brazil, E/CN.4/2005/48/Add.3. United Nations Commission on Human Rights. Accessed June 2015. http://www.refworld.org/topic,50ffbce582,50ffbce5d0,42d66e7c0,0,UNCHR,MISSION,B RA.html.

Laboratório de Pesquisas em Etnicidade, Cultura e Desenvolvimento (LACED). 2014. "Sistema de informações sobre comunidades remanescentes de quilombo: comunidade Sacopã." Accessed June 2015. http://laced.etc.br/site/sistema_quilombo/comunidade.php?idQuilombo=291 .

Lefebvre, Henri. 1996. "Right to the City." In Writings on Cities, edited and translated by Eleonore Kofman and Elizabeth Lebas, 63-181. Cambridge, Mass.: Blackwell Publishers.

Maricato, Ermínia. 2010. "The Statute of the Peripheral City." In The City Statute: A commentary, edited by Celso Carvalho Santos and Anaclaudia Rossbac. São Paulo: Cities Alliance and Brazilian Ministry of Cities. Accessed December 27, 2015. http://www.citiesalliance.org/sites/citiesalliance.org/files/CA_Images/CityStatuteofBrazi 1_English_fulltext.pdf.

Maybury-Lewis, David. 2003. "From Elimination to an Uncertain Future: Changing Policies towards Indigenous People." In At the Risk of Being Heard: Identity, Indigenous Rights, and Postcolonial States, edited by Bartholomew Dean and Jerome M. Levi, 324-334. Ann Arbor, MI: University of Michigan Press.

Mendonça, Patrícia de Castro Maia. 2011. “Ladeira Sacopã, 250. Um parque, um quilombo, um conflito sócio-ambiental na lagoa Rodrigo de Freitas." Revista Vitas, 1-23. Accessed December 22, 2015. http://www.uff.br/revistavitas/images/antigos/LADEIRA\%20SACOP\%C3\%83,\%20250\% 20UM\%20PARQUE,\%20UM\%20QUILOMBO,\%20UM\%20CONFLITO\%20por\%20Patrici a\%20Mais.pdf.

. 2010. “Quilombo Sacopã: uma história de resistência." 5th Encontro Nacional da ANPPAS, Florianópolis, SC, October 4-7. Accessed December 22, 2015. http://www.anppas.org.br/encontro5/cd/artigos/GT16-373-298-20100902225930.pdf.

Manenti, Caetano. 2014. "Único quilombo da zona sul do Rio recebe portaria do INCRA e volta a celebrar com pagode e feijoada." Jornalismo em Pé (blog), September 24. 
Accessed July 18, 2015. https://medium.com/@jornalismoempe/unico-quilombo-da-zonasul-do-rio-recebe-portaria-do-incra-e-volta-a-celebrar-com-pagode-e-feijoadabe9d6e1ee6e8.

Menezes, Bruno. 2012. “Lei protege Quilombo Sacopã, no Rio.” Epoch Times, August 23. Accessed June 23, 2015. http://www.epochtimes.com.br/lei-protege-quilombo-sacopano-rio/\#.U5uFpignLIV.

Merchant, Carolyn. 2002. The Columbia Guide to American Environmental History. New York: Columbia University Press.

Murilo, José de Carvalho. 2002. Cidadania no Brasil: o longo caminho. 3rd ed. Rio de Janeiro: Civilização Brasileira. Accessed July 14, 2015. https://politica3unifesp.files.wordpress.com/2013/01/cidadania-no-brasil-o-longocaminho.pdf.

Notícias Rio Brasil Editor. 2013. "Hospital Côlonia Curupaiti o novo endereço dos índios expulsos da Aldeia Maracanã," Notícias Rio Brasil (blog), March 23. Accessed June 24, 2015. http://noticiasriobrasil.com.br/?p=5616.

Office of the United Nations High Commissioner for Human Rights (OHCHR). 2014. The Right to Adequate Housing: Fact Sheet No. 21/Rev.1. Accessed June 22, 2015. http://www.ohchr.org/Documents/Publications/FS21_rev_1_Housing_en.pdf

Pereira, Luiz João Domingues. 2014. "Sete jogos, nehum índio." e-metropolis, June, 30-40. Accessed December 21, 2015. http://emetropolis.net/system/edicoes/arquivo_pdfs/000/000/017/original/emetropolis_n 17.pdf?1447896366.

Perlman, Janice. 2010. Favela: Four Decades of Living on the Edge in Rio de Janeiro. Oxford: Oxford University Press.

Pinheiro, Thaís Rosa. 2013. "Quilombo Alert: Meeting Discusses the Future of Quilombos." Translated by Tom Winterbottom. RioOnWatch, November 8. Accessed June 23, 2015. http://www.rioonwatch.org/?p=12090.

Rodríguez, Stella Luz Cáceres. 2013. "Naturezas monumentalizadas, cotidianos politizados: a construção discursiva do lugar no caso do Quilombo Sacopã." Sociedade e 
Cultura 16, no. 1: 91-103. Accessed December 21, 2015. http://www.redalyc.org/articulo.oa?id=70329744010.

Rolnik, Raquel. 2013. Report of the Special Rapporteur on adequate housing as a component of the right to an adequate standard of living, and on the right to non-discrimination in this context, Raquel Rolnik, A/HRC/25/54. United Nations General Assembly. Accessed June 23 , 2015. http://www.ohchr.org/EN/HRBodies/HRC/RegularSessions/Session25/Documents/AHRC-25-54_en.doc.

. 2012. "Between Mountains and Sea Rio's Favelas are a World Heritage Site." Translated by Rachel Fox. RioOnWatch, July 4. Accessed July 12, 2015. http://www.rioonwatch.org/?p=4222.

Romão, Marcos. 2012. “Quilombo Sacopã, o mundo não acabou! 2012, coragem civil é a voz de nosso silêncio." Mamapress (blog), December 25. Accessed June 23, 2015. https://mamapress.wordpress.com/2012/12/25/quilombo-sacopa-o-mundo-nao-acabou2012-coragem-civil-e-a-voz-de-nosso-silencio/.

Romero, Simon and Taylor Barnes. 2013. "Police Storm Squatters at Rio Stadium Site." New York Times, March 22. Accessed July 12, 2015. http://www.nytimes.com/2013/03/23/world/americas/brazilian-police-storm-indigenoussquatters-at-maracana.html?_r=1\&.

Sánchez, Fernanda. 2013. "Forced Eviction of Aldeia Maracanã: How Not to Make a World Cup." RioOnWatch, March 23. Accessed June 23, 2015. http://www.rioonwatch.org/?p=7962.

Sánchez, Fernanda, and Anne-Marie Broudeboux. 2013. "Mega-events and Urban Regeneration in Rio de Janeiro: Planning in a State of Emergency." International Journal of Urban Sustainable Development 5, no. 2:132-153. Accessed December 18, 2015. http://dx.doi.org/10.1080/19463138.2013.839450.

dos Santos, Ney Oliveira. 1996. Favelas and Ghettos: Race and Class in Rio de Janeiro and New York City." Latin American Perspectives 23, no. 4 (autumn): 71-89. Accessed July 17, 2015. http://www.jstor.org/stable/2634130. 
Scheper-Hughes, Nancy. 1992. Death without Weeping: The Violence of Everyday Life in Brazil. Berkeley: University of California Press.

Seed, Patricia. 2001. "No Perfect World: Aboriginal Communities' Contemporary Resource Rights." In The Latin American Subaltern Studies Reader, edited by Ileana Rodríguez, 129-142. Durham and London: Duke University Press.

Sheriff, Robin E. 2001. Dreaming Equality: Color, Race, and Racism in Urban Brazil. New Brunswick: Rutgers University Press.

Skidmore, Thomas E. 1974. Black into White: Race and Nationality in Brazilian Thought. New York: Oxford University Press.

Soares, Rafael Gonçalves. 2013. "Porto Maravilha, renovação urbana e o uso da noção de risco: uma confluência perversa no morro da Providência." Libertas 13, no. 2: 1-31. Accessed December 17 2015. http://libertas.ufjf.emnuvens.com.br/libertas/article/viewFile/2751/1962.

South African Human Rights Commission (SAHR). 2012. Section 184(3) Report: Transforming Society. Securing Rights. Restoring Dignity. Accessed June 22, 2015. http://www.sahrc.org.za/home/21/files/Section\%20184(3)\%20Report.pdf.

Spivak, Gayatri Chakravorty. 1990. The Postcolonial Critic. London: Routledge.

Sullivan, LaShandra. 2013. "Identity, Territory and Land Conflict in Brazil." Development and Change 44, no. 2 (March): 452-471. Accessed April 29, 2014. http://dx.doi.org/10.1111/dech.12010.

Tsosie, Rebecca. 1996. "Tribal Environmental Policy in an Era of Self-Determination: The Role of Ethics, Economics, and Traditional Ecological Knowledge." Vermont Law Review 21, no. 1 (Fall): 225-333. Accessed June 10, 2014. home.heinonline.org.

Twine, France Winddance. 1997. Racism in a Racial Democracy: The Maintenance of White Supremacy in Brazil. New Brunswick: Rutgers University Press.

Virtanen, Pirjo Kristiina. 2012. Indigenous Youth in Brazilian Amazonia: Changing Lived World. New York: Palgrave Macmillan.

3RASILIANA- Journal for Brazilian Studies. Vol. 4, n.2 (2016). ISSN 2245-4373. 
Warren, Jonathan W. 2001. Racial Revolutions: Antiracism and Indian Resurgence in Brazil. Durham, NC: Duke University Press.

Williamson, Theresa and Maurício Hora. 2012. "In the Name of the Future, Rio Is Destroying Its Past." New York Times, August 12. Accessed July 12, 2015. http://www.nytimes.com/2012/08/13/opinion/in-the-name-of-the-future-rio-isdestroying-its-past.html?_r=0.

Winant, Howard. 1992. "Rethinking Race in Brazil." Journal of Latin American Studies 24, no. 3 (February): 173-92. Accessed November 24, 2015. http://links.jstor.org/sici?sici=0022216X\%28199202\%2924\%3A1\%3C173\%3ARRIB\%3E2.0.CO\%3B2-F.

Xanthaki, Alexandra. 2007. Indigenous Rights and United Nations Standards: SelfDetermination, Culture and Land. Cambridge: Cambridge University Press. Accessed June 8, 2014. http://dx.doi.org/10.1017/CBO9780511494468.

Yashar, Deborah J. 2005. Contesting Citizenship in Latin America: The Rise of Indigenous Movements and the Postliberal Challenge. Cambridge: Cambridge University Press. 